\title{
Lymphocyte subpopulations in primary immunodeficiency disorders
}

\author{
E G DAVIES, R J LEVINSKY, M BUTLER, R M THOMAS, AND D C LINCH
}

Department of Immunology, Institute of Child Health; Department of Haematology, University College Hospital, London

SUMMARY Venous blood mononuclear cells from 42 children with primary immunodeficiency disorders and from controls matched for age were studied for lymphocyte subpopulations by $\mathrm{E}$ rosetting, surface immunoglobulin, and a panel of anti $T$ cell monoclonal antibodies (OKT series). In 3 cases of severe combined immunodeficiency (SCID) due to adenosine deaminase deficiency, very few circulating $T$ or B cells were found. The other 7 cases of SCID all had normal or, in 3 cases, very high numbers of circulating B cells, but in 6 of these very few cells showed T cell markers. One child had very high numbers of $B$ cells and $T$ cells with an immature pattern of reactivity similar to that found on common thymocytes. In $T$ cell deficient children no consistent pattern was found, but in those with cartilage hair hypoplasia with immunodeficiency there was a low helper (OKT4) to suppressor (OKT8) ratio and high numbers of circulating OKT10 positive cells. In cases of X-linked agammaglobulinaemia circulating B cells were not found but the pattern of $\mathbf{T}$ cell markers was normal. In cases of common variable hypogammaglobulinaemia there was a wide scatter of helper (OKT4) to suppressor (OKT8) cell ratios. Five children were studied before and after treatment with the synthetic thymic hormone preparation TP5. There were appreciable alterations in the pattern of staining with anti $\mathrm{T}$ cell monoclonal antibodies in 4 of these cases, but in 1 case only was this accompanied by improvements in clinical and immune function.

The study of primary immunodeficiency diseases in man has provided much information on the development and maturation of the human immune system. The discovery of monoclonal antisera that recognise different subpopulations of immature and mature lymphocytes has allowed better analysis. This may prove useful in increasing understanding of the immune system and will allow more logical classification of immunodeficiency disorders. Analysis of lymphocyte subpopulations by monoclonal antisera has recently been applied to the prenatal diagnosis of severe combined immunodeficiency. ${ }^{1}$

We report data on circulating lymphocyte subpopulations analysed by monoclonal antisera in 42 children with primary immunodeficiencies affecting either cell mediated immunity or humoral immunity or both. Samples from controls matched for age were analysed.

\section{Methods}

Patients and controls. Blood was taken from healthy children aged 8 months to 11 years who were being tested before minor cold surgical procedures, such as hernia repairs, but not including conditions where immunopathology might exist-for example, tonsillectomies. Younger controls were healthy term neonates tested in the first week of life.

The 42 patients studied had primary immunodeficiency as defined by WHO criteria. ${ }^{2}$ Six children with cartilage hair hypoplasia syndrome were included in the study, as primary immunodeficiency is believed to be a feature of this syndrome. ${ }^{3}$ At the time of testing none of the patients, apart from those with X-linked agammaglobulinaemia who were receiving intramuscular gammaglobulin, were receiving or had received any treatment likely to affect the immune system. Five patients were studied after treatment with the synthetic thymic hormone TP5 (Ortho Pharmaceuticals) $(0 \cdot 25-1 \mathrm{mg} / \mathrm{kg}, 3$ times a week, subcutaneously). All tests on control and immunodeficient children were performed with the approval of the hospital ethical committees.

In all the patients and in the older group of controls mononuclear cell preparations from blood were prepared by Ficoll Hypaque (Lymphoprep 
Flow Laboratories) density centrifugation. In the term neonates total leucocyte preparations were made by Hetastarch sedimentation, ${ }^{4}$ which allows analysis of small quantities of blood. In 8 of the older children both methods of separation were tested in parallel. The ratios of the various subpopulations to each other were very similar by both methods, though the percentage values obtained for individual populations were, of course, lower in the Hetastarch separated preparations.

$T$ cell percentages were counted by sheep cell rosetting ( $E$ rosetting, using neuraminidase treated sheep red cells). ${ }^{5}$ B cell numbers were estimated by direct immunofluorescence using a polyvalent antihuman immunoglobulin. ${ }^{6}$ Monoclonal antibody staining was performed by incubating the mononuclear cells with the particular monoclonal antibody and then washing extensively with a fluoresceinated sheep antimouse antibody. Cells were counted either by fluorescence microscopy or by flow fluorocytometery (FACS IV). In a proportion of cases both methods of analysis were used and gave comparable results. B cell numbers were estimated by fluorescence microscopy only.

The monoclonal antibodies used were either those of the OKT series ${ }^{7}$ (Ortho Kung T-Cells, Ortho Pharmaceuticals) or equivalents. OKT3 stains all mature T cells (equivalent UCHT1). ${ }^{8}$ OKT4 stains the helper/inducer subset, and OKT8 stains the suppressor/cytotoxic subset (equivalents Leu 3A and Leu 2A). ${ }^{9}$ OKT6 recognises cortical thymocytes (equivalent $\mathrm{Na134})^{\mathbf{1 0}}$ and OKT10 stains most thymocytes, but is reported to stain less than $10 \%$ of circulating lymphocytes. ${ }^{11}$

\section{Results}

Normal controls. Lymphocyte counts and $T$ cell subsets in control subjects of different ages are shown in Table 1. Total lymphocyte counts were higher in the younger children. OKT4:OKT8 ratios were also higher, though the difference between the age groups was not statistically significant. We did not count $E$ rosette numbers on the control children and though we did count $B$ cell numbers we have not included these data because all control data were obtained using the cell sorter while all the patients' B cell numbers were counted by fluorescence microscopy. Although there was good correlation between the two methods when counting $T$ cell subsets, we found that $B$ cell numbers counted on the cell sorter were usually much higher than when counted by fluorescence microscopy-probably because it is easier to distinguish by microscopy true surface immunoglobulin positive cells from those cells with surface immunoglobulin staining due to Fc' receptor binding (ie monocytes). The normal ranges included in Table 2 are derived therefore from retrospective analysis of data obtained from either healthy adults or children who underwent

Table $1 T$ cell subsets in 42 normal children (mean value $\pm 1 S D$ )

\begin{tabular}{|c|c|c|c|c|c|c|}
\hline Age & No & $\begin{array}{l}\text { Lymphocytes } \\
\left(\times 10^{9} / l\right)\end{array}$ & $\begin{array}{l}\text { OKT3† } \\
(\%)\end{array}$ & $\begin{array}{l}O K T 4 \dagger \\
(\%)\end{array}$ & $\begin{array}{l}\text { OKT8† } \\
(\%)\end{array}$ & $\begin{array}{l}\text { Ratio } \\
\text { OKT4:8 }\end{array}$ \\
\hline $\begin{array}{l}0-1 w^{*} \\
1 \mathrm{wk}-2 \mathrm{yr} \\
2 \mathrm{yr}-11 \mathrm{yr}\end{array}$ & $\begin{array}{r}10 \\
5 \\
17\end{array}$ & $\begin{array}{r}4 \cdot 0 \pm 2 \cdot 45 \\
7 \cdot 52 \pm 4 \cdot 47 \\
3 \cdot 3 \pm 1 \cdot 74\end{array}$ & $\begin{array}{l}34 \pm 17 \\
67 \pm 15 \\
65 \pm 12\end{array}$ & $\begin{array}{l}24 \pm 13 \\
42 \pm 7 \\
42 \pm 10\end{array}$ & $\begin{array}{l}13 \pm 7 \\
24 \pm 11 \\
24 \pm 8\end{array}$ & $\begin{array}{c}2 \cdot 0 \pm 1 \cdot 3 \\
2 \cdot 14 \pm 1 \cdot 15 \\
1 \cdot 83 \pm 0 \cdot 58\end{array}$ \\
\hline
\end{tabular}

*Cells separated by Hetastarch method; tpercentage of cells staining with monoclonal antibodies (OKT series or equivalents).

Conversion: SI to traditional units-Lymphocytes $1 \times 109 / 1 \approx 1000 / \mathrm{mm}^{3}$.

Table 2 Severe combined immunodeficiency (SCID)

\begin{tabular}{|c|c|c|c|c|c|c|c|c|c|c|c|}
\hline Case no & Diagnosis & Sex & $\begin{array}{l}\text { Age } \\
\text { (months) }\end{array}$ & $\begin{array}{l}\text { Lymphocytes } \\
\left(\times 10^{9} / l\right)\end{array}$ & $\begin{array}{l}\text { E rosettes } \\
(\%) \\
\text { (normal } \\
\text { range } \\
55-75 \%)\end{array}$ & $\begin{array}{l}\text { B cells } \\
(\%) \\
(\text { normal } \\
\text { range } \\
5-20 \%)\end{array}$ & $\begin{array}{l}\text { OKT3 } \\
(\%)\end{array}$ & $\begin{array}{l}\text { OKT4 } \\
(\%)\end{array}$ & $\begin{array}{l}\text { OKT8 } \\
(\%)\end{array}$ & $\begin{array}{l}\text { OKT6 } \\
(\%)\end{array}$ & $\begin{array}{l}\text { OKTIO } \\
(\%)\end{array}$ \\
\hline 1 & ADA-SCID & $\mathbf{M}$ & 2 & $0 \cdot 1$ & 1 & 1 & 3 & 2 & 6 & 4 & - \\
\hline 2 & ADA-SCID & $\mathbf{F}$ & 4 & $0 \cdot 2$ & 0 & 0 & 0 & $\mathbf{0}$ & 0 & 0 & - \\
\hline 3 & ADA-SCID & $\mathbf{M}$ & 7 & $0 \cdot 1$ & 0 & 0 & 2 & 0 & $\mathbf{0}$ & 一 & - \\
\hline $5^{*}$ & SCID & $\mathbf{M}$ & 1 & $2 \cdot 4$ & 2 & 25 & 0 & $\mathbf{0}$ & 0 & $\mathbf{0}$ & 9 \\
\hline 6 & SCID & $\mathbf{M}$ & 6 & $2 \cdot 2$ & 0 & 68 & 1 & 1 & 0 & - & 一 \\
\hline 7 & SCID & $\mathbf{M}$ & 6 & $7 \cdot 0$ & 0 & 58 & 37 & 22 & 41 & 45 & - \\
\hline 8 & SCID & $\mathbf{M}$ & 5 & 0.4 & 6 & 9 & 9 & $\mathbf{0}$ & 6 & 0 & 0 \\
\hline 9 & SCID & $\mathbf{M}$ & 18 & $1 \cdot 2$ & 2 & 20 & 10 & 0 & 7 & - & - \\
\hline 10 & SCID & $\mathbf{F}$ & 1 & $1 \cdot 0$ & 1 & 26 & 4 & 1 & 1 & - & - \\
\hline
\end{tabular}

ADA = adenosine deaminase deficient.

*Siblings. 
Table 3 Cell mediated immunodeficiency

\begin{tabular}{|c|c|c|c|c|c|c|c|c|c|c|c|c|}
\hline $\begin{array}{l}\text { Case } \\
\text { no }\end{array}$ & Diagnosis & Sex & $\begin{array}{l}\text { Age } \\
\text { (years) }\end{array}$ & $\begin{array}{l}\text { Lymphocytes } \\
\left(\times 10^{9} / l\right)\end{array}$ & $\begin{array}{l}\text { E rosettes } \\
(\%) \\
\text { (normal } \\
\text { range } \\
55-75 \%)\end{array}$ & $\begin{array}{l}\text { B cells } \\
(\%) \\
\text { (normal } \\
\text { range } \\
5-20 \%)\end{array}$ & $\begin{array}{l}\text { OKT3 } \\
(\%)\end{array}$ & $\begin{array}{l}\text { OKT4 } \\
(\%)\end{array}$ & $\begin{array}{l}\text { OKT8 } \\
(\%)\end{array}$ & $\begin{array}{l}\text { OKT6 } \\
(\%)\end{array}$ & $\begin{array}{l}\text { OKTIO } \\
(\%)\end{array}$ & $\begin{array}{l}\text { Ratio } \\
\text { OKT4:8 }\end{array}$ \\
\hline 11 & Di George syndrome & $\mathbf{F}$ & $3 \mathrm{mth}$ & $2 \cdot 7$ & 6 & 一 & 31 & 46 & 14 & 0 & 16 & $3 \cdot 3$ \\
\hline 12 & Di George syndrome & $\mathbf{F}$ & $2 \mathrm{wk}$ & $2 \cdot 1$ & 33 & 一 & 50 & 31 & 19 & 2 & 一 & $1 \cdot 6$ \\
\hline 13 & $T$ cell defect & $\mathbf{F}$ & $8 \mathrm{mth}$ & 0.75 & $12-32$ & 4 & 32 & 11 & 6 & 0 & - & $1 \cdot 8$ \\
\hline 15 & $T$ cell defect & $\mathbf{F}$ & 11 & $2 \cdot 3$ & 46 & 18 & 52 & 40 & 11 & 2 & 一 & $3 \cdot 6$ \\
\hline 16 & Variable ID & $\mathbf{M}$ & 10 & $2 \cdot 3$ & 46 & 18 & 52 & 40 & 11 & 2 & - & $3 \cdot 6$ \\
\hline $17 \dagger$ & Variable ID & $\mathbf{M}$ & 3 & $5 \cdot 8$ & 70 & 13 & 75 & 25 & 28 & 0 & 一 & 0.9 \\
\hline $18 \dagger$ & Variable ID & $\mathbf{M}$ & $9 \mathrm{mth}$ & 0.5 & 50 & 0 & 44 & 30 & 14 & - & - & $2 \cdot 1$ \\
\hline $19 *$ & CHH & $\mathbf{F}$ & 10 & $1 \cdot 2$ & 54 & 9 & 40 & 18 & 15 & 1 & 36 & $1 \cdot 2$ \\
\hline $20 *$ & CHH & $\mathbf{F}$ & $2 \frac{1}{2}$ & $7 \cdot 4$ & 54 & - & 67 & 39 & 19 & 0 & 24 & $2 \cdot 1$ \\
\hline $21 *$ & $\mathrm{CHH}$ & $\mathbf{F}$ & $2 \frac{1}{2}$ & $2 \cdot 1$ & 44 & - & 51 & 42 & 17 & 0 & 25 & $2 \cdot 5$ \\
\hline 22 & CHH & $\mathbf{M}$ & 15 & 0.2 & 45 & 5 & 39 & 21 & 16 & 0 & 18 & $1 \cdot 3$ \\
\hline $23^{*}$ & CHH & $\mathbf{F}$ & 14 & $3 \cdot 0$ & 75 & 2 & 72 & 41 & 23 & 0 & 7 & $1 \cdot 8$ \\
\hline
\end{tabular}

ID = immunodeficiency; $\mathbf{C H H}=$ cartilage hair hypoplasia; WA = Wiskott-Aldrich syndrome.

*Siblings; tpredominantly $\mathrm{T}$ cell defect in these children.

immunological investigation, but who were subsequently thought to be normal.

\section{Patients}

Severe combined immunodeficiency (SCID) (Table 3) Ten patients with SCID were studied. Three had adenosine deaminase (ADA) deficiency and were found to be lymphopenic with absent $T$ and $B$ cells and virtually no cells reacting with the monoclonal antisera used.

Seven patients had circulating B cells (SCID with $B$ cells) and in 3 cases $B$ cell numbers were very high. None of these children had more than a few per cent cells which formed $E$ rosettes and in 6 of them only very small numbers of cells reacted with the monoclonal antisera. One patient, however, (case 7) had circulating cells that reacted with OKT3, 4, 8, and 6 . We did not do double staining analysis, but by adding the percentages of cells reactive with each antiserum we found that many of the cells had all these antigens (ie had the phenotype $\mathrm{OKT}^{+}, 4^{+}$, $\left.6^{+}, 8^{+}\right)$. This patient's cells were lacking in function, however, as shown by the absence of responsiveness to mitogen stimulation and mixed lymphocyte culture (data not shown).

\section{Cell mediated immunodeficiency (Table 3)}

This group of 15 patients with cell mediated immunodeficiency had heterogeneous immunodeficiencies affecting predominantly the $T$ cell system. Two cases of partial Di George syndrome were tested. One showed low total $\mathrm{T}$ cell numbers (E rosettes and OKT3 positive cells) and OKT8 positive cells. OKT4 positive cells were present in normal numbers resulting in a high OKT4:8 ratio.
Numbers of OKT10 positive cells were high. The other patient had low numbers of $T$ cells but a normal ratio of OKT4 to OKT8 positive cells.

Three children with cell mediated immunodeficiency had normal immunoglobulin values. The first child (case 13) was very lymphopenic and had variable but always low $\mathrm{E}$ rosette positive cell numbers, but a normal OKT4:8 ratio. The other 2 children had low $\mathrm{T}$ cell numbers with high OKT4:8 ratios. Three children had cell mediated immunodeficiency with low values of one or more immunoglobulin classes. No consistent pattern was found in these cases. The 1 case of Wiskott-Aldrich syndrome had a high OKT4:8 ratio and high numbers of OKT10 positive cells.

The remainder of this group comprised 6 cases (from 3 families) of cartilage hair hypoplasia syndrome. Two of these children did not give a clinical history of immunodeficiency while the other 4 had histories of recurrent chest infections and candidiasis. These 4 children had high numbers of OKT10 positive cells in the circulation and the 2 older ones (who had histories suggesting more severe immunodeficiency) had low total $\mathrm{T}$ cell numbers and low OKT4:8 ratios.

\section{Hypogammaglobulinaemia (Table 4)}

As only 2 cases of $\operatorname{IgA}$ deficiency were studied no conclusions can be drawn. In 6 cases of X-linked agammaglobulinaemia, apart from absence of circulating B cells, other lymphocyte populations and the OKT4:8 ratios were normal. In common variable hypogammaglobulinaemia ( 9 cases studied) circulating B cells were present and $T$ cell numbers were normal. Abnormal OKT4:8 ratios were found in 2 cases-in one the ratio was very high 
Table 4 Hypogammaglobulinaemia

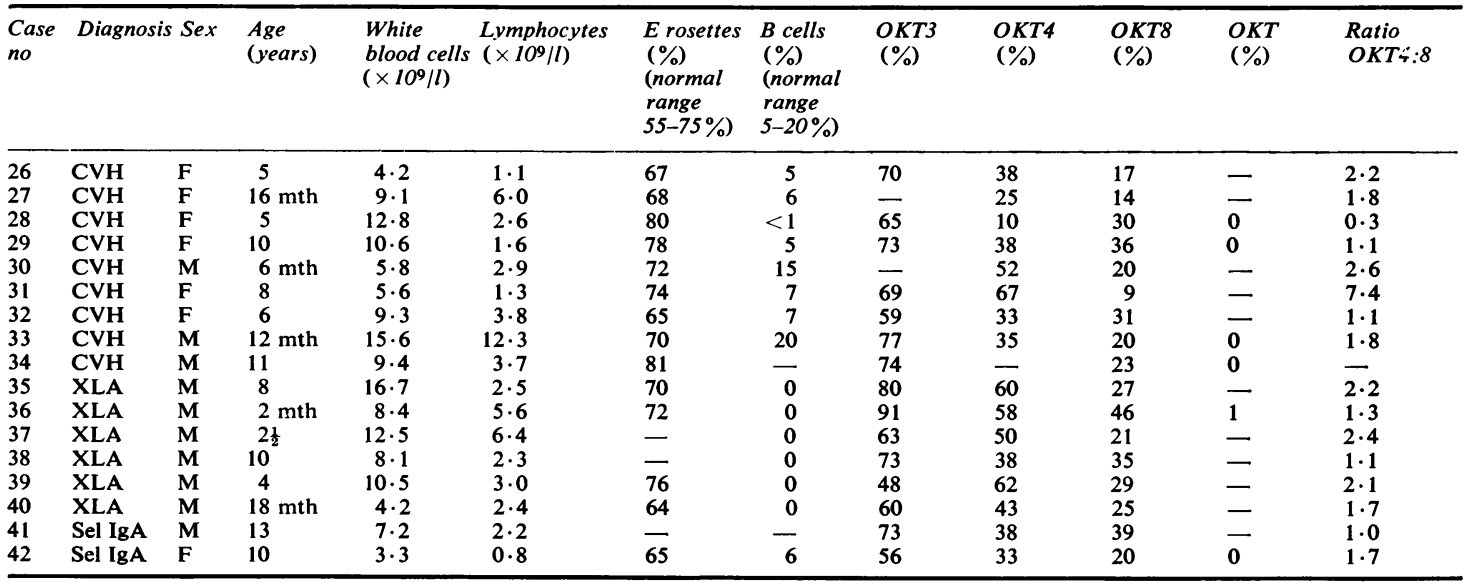

$\mathbf{C V H}=$ common variable hypogammaglobulinaemia; XLA =X-linked hypogammaglobulinaemia; SelIgA= selective IgA deficiency.

$(7 \cdot 4)$ and in the other very low $(0 \cdot 3)$. The other 7 children all had OKT4:8 ratios in the normal range.

\section{Effect of TP5 treatment}

Five patients were treated with TP5 and their sequential subpopulation data are shown in Table 5 . The full details of these cases have been reported elsewhere. ${ }^{12}$ One child only showed a good clinical response to treatment. In her case the first course of treatment produced a rise in circulating $T$ cell numbers and many of these cells had the common thymocyte phenotype, but after stopping the drug for
1 month her $\mathrm{T}$ cell numbers fell. When a second course was given $T$ cell numbers rose, but this time there was no rise in OKT6 positive cells. It is interesting that functional responses improved much more during the second course of treatment than the first (data not shown).

None of the other cases responded well to treatment but 2 interesting points emerged. Firstly, in 1 case of SCID, cells bearing the OKT4 and OKT8 markers could be induced. These cells were not functional and did not express the OKT3 marker or the $\mathrm{E}$ rosette receptor. Secondly, in two children with hypogammaglobulinaemia OKT4:8 ratios

Table $5 T$ cell subsets in immunodeficient children after treatment with TP5

\begin{tabular}{|c|c|c|c|c|c|c|c|c|}
\hline $\begin{array}{l}\text { Case details } \\
\text { No, age, sex, } \\
\text { diagnosis }\end{array}$ & Time of testing & $\begin{array}{l}\text { Lymphocytes } \\
\left(\times 10^{9} / l\right)\end{array}$ & $\begin{array}{l}\text { E rosettes } \\
(\%) \\
(\text { normal range } \\
55-75 \%)\end{array}$ & $\begin{array}{l}\text { B cells } \\
(\%) \\
(\text { normal range } \\
5-20 \%)\end{array}$ & $\begin{array}{l}O K T 3 \\
(\%)\end{array}$ & $\begin{array}{l}\text { OKT4 } \\
(\%)\end{array}$ & $\begin{array}{l}O K T 8 \\
(\%)\end{array}$ & $\begin{array}{l}\text { OKT6 } \\
(\%)\end{array}$ \\
\hline $\begin{array}{l}13.8 \mathrm{mth}, \mathrm{F} \text {, } \\
\mathrm{T} \text { cell deficient }\end{array}$ & $\begin{array}{l}\text { Before treatment } \\
1 \mathrm{mth} \\
3 \mathrm{mth} \\
1 \mathrm{mth} \text { off TP5 } \\
1 \mathrm{yr} \text { on TP5 }\end{array}$ & $\begin{array}{l}0.8 \\
0.7 \\
0.3 \\
0.9 \\
0.3\end{array}$ & $\begin{array}{l}12-32 \\
32 \\
54 \\
40 \\
47\end{array}$ & $\begin{array}{r}4 \\
11 \\
14 \\
10 \\
-\end{array}$ & $\begin{array}{l}32 \\
30 \\
45 \\
30 \\
30\end{array}$ & $\begin{array}{l}11 \\
16 \\
43 \\
15 \\
13\end{array}$ & $\begin{array}{r}6 \\
20 \\
27 \\
18 \\
25\end{array}$ & $\begin{array}{r}<1 \\
19 \\
21 \\
5 \\
0\end{array}$ \\
\hline $\begin{array}{l}4.6 \mathrm{mth}, \mathrm{M}, \\
\text { SCID }\end{array}$ & $\begin{array}{l}\text { Before treatment } \\
1 \mathrm{mth} \\
3 \mathrm{mth} \\
1 \mathrm{mth} \text { off TP5 }\end{array}$ & $\begin{array}{r}5 \cdot 8 \\
8 \cdot 4 \\
7 \cdot 0 \\
10 \cdot 5 \\
\end{array}$ & $\begin{array}{r}2 \\
12 \\
3 \\
5\end{array}$ & $\begin{array}{l}68 \\
54 \\
58 \\
60\end{array}$ & $\begin{array}{l}7 \\
3 \\
3 \\
8\end{array}$ & $\begin{array}{r}3 \\
3 \\
19 \\
22\end{array}$ & $\begin{array}{r}0 \\
4 \\
13 \\
16\end{array}$ & $\begin{array}{r}\overline{3} \\
<1 \\
<1\end{array}$ \\
\hline $\begin{array}{l}2 . * 6 \text { mth, F, } \\
\text { ADA/SCID }\end{array}$ & $\begin{array}{l}\text { Before treatment } \\
1 \mathrm{mth}\end{array}$ & $\begin{array}{l}0.2 \\
0.7\end{array}$ & $\begin{array}{l}0 \\
3\end{array}$ & $\begin{array}{l}0 \\
2\end{array}$ & $\begin{array}{r}1 \\
10\end{array}$ & $\begin{array}{l}3 \\
1\end{array}$ & $\begin{array}{l}1 \\
8\end{array}$ & $\begin{array}{l}1 \\
0\end{array}$ \\
\hline $\begin{array}{l}28.5 \text { yr, F, } \\
\text { CVH }\end{array}$ & $\begin{array}{l}\text { Before treatment } \\
1 \mathrm{mth} \\
3 \mathrm{mth} \\
1 \mathrm{mth} \text { off TP5 } \\
6 \mathrm{mth} \text { on TP5 } \\
\end{array}$ & $\begin{array}{l}2 \cdot 6 \\
3 \cdot 5 \\
2 \cdot 2 \\
3 \cdot 7 \\
3 \cdot 2 \\
\end{array}$ & $\begin{array}{l}80 \\
75 \\
83 \\
88 \\
57 \\
\end{array}$ & $\begin{array}{r}<1 \\
3 \\
6 \\
2 \\
7 \\
\end{array}$ & $\begin{array}{l}65 \\
76 \\
77 \\
76 \\
41 \\
\end{array}$ & $\begin{array}{l}10 \\
19 \\
29 \\
25 \\
30\end{array}$ & $\begin{array}{l}30 \\
49 \\
51 \\
85 \\
48 \\
\end{array}$ & $\begin{array}{l}0 \\
0 \\
0 \\
0 \\
0\end{array}$ \\
\hline $\begin{array}{l}29.8 \mathrm{yr}, \mathrm{F}, \\
\text { CVH }\end{array}$ & $\begin{array}{l}\text { Before treatment } \\
1 \mathrm{mth} \\
3 \mathrm{mth} \\
1 \mathrm{mth} \text { off TPS }\end{array}$ & $\begin{array}{l}1 \cdot 6 \\
1 \cdot 6 \\
2 \cdot 0 \\
1 \cdot 2\end{array}$ & $\begin{array}{l}78 \\
74 \\
64 \\
40\end{array}$ & $\begin{array}{l}5 \\
4 \\
3 \\
3\end{array}$ & $\begin{array}{l}73 \\
83 \\
61 \\
47\end{array}$ & $\begin{array}{l}38 \\
38 \\
35 \\
30\end{array}$ & $\begin{array}{l}36 \\
53 \\
27 \\
30\end{array}$ & $\begin{array}{l}\mathbf{0} \\
\mathbf{0} \\
\mathbf{0} \\
\mathbf{0}\end{array}$ \\
\hline
\end{tabular}

SCID = severe combined immunodeficiency; ADA = adenosine deaminase deficient; $\mathbf{C V H}=$ common variable hypogammaglobulinaemia. * Concurrently given treatment with fresh irradiated erythrocytes. 
were low before treatment. At first TP5 seemed to boost the OKT8 subpopulation, resulting in an even lower ratio. Subsequently as the OKT4 subpopulation rose the ratios improved but never reached the original values. It is not known whether these changes in the OKT4:8 ratios correlated with functional help and suppression.

\section{Discussion}

In this study we analysed lymphocyte subpopulations by surface markers in children with a variety of primary immunodeficiency syndromes and in controls matched for age. The results on control children showed that circulating lymphocyte numbers are raised in infancy and that the ratio of OKT4:OKT8 (helper/suppressor) positive cells is slightly higher in the younger age group. Apart from the OKT4:8 ratio, the data on the neonatal group are not comparable with the rest because the percentages obtained were of total white cells rather than isolated mononuclear cells. The results in our older group of children did not differ appreciably from our findings in healthy adults (data not shown) or from the findings in other studies. ${ }^{13}$

In the SCID group we found that ADA deficient children were lymphopenic with very low or absent $T$ and $B$ cells and no cells staining with the monoclonal anti $T$ antibodies used. In a previous case report of one of these patients (case 1) we showed that treatment with irradiated fresh red cell transfusions could induce the appearance in the circulation of low numbers of lymphocytes becoming $T$ cell markers identified by $E$ rosetting or monoclonal antibodies. ${ }^{14}$ The other 7 cases of SCID had circulating B cells (in some cases very high numbers). All but 1 of these children were boys, showing that not all cases of 'SCID with B cells,' exhibit X-linked inheritance. Six of the cases with B cells had few circulating cells staining with any of the anti $\mathrm{T}$ monoclonals, but in 1 child with SCID who had very low E rosettes the cells carried the OKT3, 4,8 , and 6 antigens and many of these cells were probably multiple staining - that is, with a phenotype found only in precursors. Further studies on lymphocytes from this patient confirmed that cells with such immature phenotypes have no functional ability. Previous reports of lymphocyte subpopulations in SCID have identified several different groups classified according to the pattern of staining with panels of anti $T$ monoclonals, ${ }^{11} 15$ but as far as we know the pattern shown in our child has not been reported.

In the 15 children with defects of cell mediated immunodeficiency we found no consistent patterns. This reflected the heterogeneity of the conditions included in this group. In the 2 cases of Di George syndrome one only showed the high OKT4:8 ratio which has been reported. ${ }^{11}$ The children with cartilage hair hypoplasia with evidence of immunodeficiency (4 out of the 6 cases) did, however, show a pattern of low OKT4:8 ratios and high numbers of circulating OKT10 positive cells.

Children with X-linked agammaglobulinaemia with no circulating B cells showed OKT4:8 ratios in the normal range. Common variable hypogammaglobulinaemia is a heterogeneous condition confirmed by the wide scatter of OKT4:8 ratios that we found. One child with a very high OKT4:8 ratio has suffered from a variety of autoimmune problems (uveitis, arthritis, immune thrombocytopenia). Though her relative lack of suppressor cells might explain these problems, it is difficult to explain her IgG and IgA deficiency. In case 28 a very low OKT4:8 ratio was found, but we cannot claim this as the sole cause of her hypogammaglobulinaemia because she was chronically infected with adenovirus and it is known that virus infections can result in a low ratio. ${ }^{16}$

The data on the patients studied after TP5 treatment indicate that this thymic hormone preparation has biological activity in vivo and is capable of inducing the appearance on $T$ cells of differentiation markers. In the SCID and common variable hypogammaglobulinaemia patients, however, it was not of therapeutic benefit since the immune function was not improved.

Our analysis of lymphocyte subpopulations by the monoclonal antisera currently available has not provided a better classification of primary immunodeficiency diseases, but as more reagents that recognise better defined cell populations become available so improvements in diagnosis may arise. The major advance to date using these monoclonal reagents has been the ability to provide prenatal diagnosis for all varieties of severe combined immunodeficiency and this has now been achieved in two centres. ${ }^{417}$

We thank Ortho Pharmaceuticals for providing us with TP5 and the OKT monoclonal antibodies, and Dr Peter Beverley for the gifts of the other monoclonal reagents used.

EGD and RMT hold research training fellowships from Action Research-The National Fund for Research into Crippling Diseases. DCL is a Wellcome Research Fellow.

\section{References}

1 Linch D C, Rodeck H C, Simmonds H A, Levinsky R J. Prenatal diagnosis of severe combined immunodeficiency. In: Rosen F S, Wedgewood R A, Paul N, eds. Inter- 
national workshop on primary immunodeficiency disorders. New York: Liss, 1982: in press.

2 World Health Organisation. Immunodeficiency. WHO Tech Rep Ser 1978; 630.

3 Ammann A J, Sutliff W, Millinchick E. Antibodymediated immunodeficiency in short-limbed dwarfism. $J$ Pediatr 1974; 84: 200-3.

' Linch D C, Beverley P C L, Levinsky R J, Rodeck C H. Phenotypic analysis of foetal blood leucocytes: potential for prenatal diagnosis of immunodeficiency disorders. Prenatal Diagnosis 1982; 2: 211-8.

5 Trompeter R S, Layward L, Hayward A R. Primary and secondary abnormalities of $\mathrm{T}$ cell subpopulations. Clin Exp Immunol 1978; 34: 388-92.

- Hayward A R. Immunodeficiency. Current Topics in Immunology, Series 6. London: Arnold, 1977: 75.

7 Reinherz E L, Schlossman S F. The differentiation and function of human T lymphocytes. Cell 1980; 19: 821-7.

8 Beverley P C L, Callard R E. Distinctive functional characteristics of human $T$ lymphocytes defined by $E$ rosetting or a monoclonal anti-T cell antibody. Eur $J$ Immunol 1981; 11: 329-34.

9 Evans R L, Wall D W, Platsoucas C D, et al. Thymus dependent membrane antigens in man: inhibition of cellmediated lympholysis by monoclonal antibodies to TH2 antigen. Proc Natl Acad Sci USA 1981 ; 78: 544-8.

10 McMichael A J, Pilch J R, Galfré G, Mason D Y, Fabre J W, Milstein C. A human thymocyte antigen defined by a hybrid myeloma monoclonal antibody. Eur $J$ Immunol 1979; 9: 205-10.

11 Reinherz E L, Cooper M D, Schlossman S F, Rosen F S. Abnormalities of $T$ cell maturation and regulation in human beings with immunodeficiency disorders. $J$ Clin Invest 1981 ; 68: 699-705.

12 Davies E G, Levinsky R J, Goldstein G. Effect of synthetic thymic hormone (TP5) in children with T cell immuno-deficiencies. In Rosen $F \mathbf{S}$, Wedgewood $R A$, Paul N, eds. International workshop on primary immunodeficiency disorders. New York: Liss, 1982: in press.

13 Leung D Y M, Rhodes A R, Geha R S. Enumeration of $T$ cell subsets in atopic dermatitis using monoclonal antibodies. J Allergy Clin Immunol 1981; 67: 450-5.

14 Davies E G, Levinsky R J, Webster D R, Simmonds H A, Perrett D. Effect of red cell transfusions, thymic hormone, and deoxycytidine in severe combined immunodeficiency due to adenosine deaminase deficiency. Clin Exp Immunol 1982; 50: 303-10.

15 Phan-Dinh-Tuy F, Durandy A, Griscelli C, Bach M A. $T$ cell subset analysis by monoclonal antibodies in primary immunodeficiencies. Scand J Immurol 1981; 14: 193-200.

16 Reinherz E L, O'Brien C, Rosenthal P, Schlossman S F. The cellular basis for viral induced immunodeficiency: analysis by monoclonal antibodies. J Immunol 1980; 125: 1269-74.

17 Durandy A, Griscelli C, Dumez Y, et al. Letter: Antenatal diagnosis of severe combined immunodeficiency from fetal cord blood. Lancet 1982 ; i: 852-3.

Correspondence to Dr R J Levinsky, Department of Immunology, Institute of Child Health, 30 Guilford Street, London WC1N 1EH.

Received 24 January 1983

British Paediatric Association

Annual meetings

1984 10-14 April York University

1985 16-20 April York University

1986 15-19 April York University

1987 7-11 April York University 